\title{
N. Clumeck
}

\section{Epidemiological Correlations Between African AIDS and AIDS in Europe}

AIDS was first recognized among Africans in late 1982 in male and female patients either resident in or referred to Belgium for care (1-3). As of September 1985, 157 cases of AIDS among people originating from 22 African countries (63\% from Zaire and $10 \%$ from the Congo) were diagnosed in eight European countries, mainly Belgium, France and Switzerland. These persons represented $10 \%$ of the 1,573 cases of AIDS who had been reported so far in Europe (4). Characteristically the male: female ratio is 2:1 and the majority (141 out of 157 patients) of African patients do not belong to the homosexual or intravenous drug user groups which account for $69 \%$ and $8 \%$, respectively, of the European cases.

The African AIDS patients living in Europe or seeking care originate from the Equatorial belt. They represent only part of the victims of the epidemic which does exist and has recently been recognized in Rwanda, Zaire, Zambia and Uganda (5-8). Nevertheless, as of March 1986, only four African nations (Zambia, Tanzania, Kenya and Soudan) officially disclosed few AIDS cases to the WHO. This under-reporting which is in sharp contrast to the results of scientific investigations, could be due to the difficulty to make an accurate diagnosis in many countries with collapsed sanitary systems, but it is more likely linked to political problems (9). The fear to be designated as the skapegoat, the fear of racism and discriminating campaigns, the possible loss of foreign currency and tourism in the present madness $(10)$ are likely reasons for many African governments to minimize the extent of the problem.

The virological, epidemiological and clinical patterns of AIDS in Africa are quite different from those observed in Northern countries. Genomic heterogeneity of AIDS retroviral isolates from Zaïre has been reported as compared to those from North America and Europe (11). In addition, very recently, viral isolates (named LAV-2) related by their glycoprotein to the Simian T Lymphotropic Virus type III (STLV-3) and by their core proteins to the LAV-1, have been found in AIDS patients originating from West Africa (Cap Vert and Guinea-Bissau) (12). Furthermore, antibodies against STLV-3 and the virus itself (named HTLV-IV), have been demonstrated among residents of Senegal, but as yet with no history of AIDS or AIDS-related illness $(13,14)$. In addition, HTLV-III/ LAV has been shown to be linked to Visna Virus and to Bovine Leukemia Virus (14). Thus, it is likely that the Human $T$ Lymphotropic Viruses are related to a continuum of genomic evolution from a common animal predecessor (non-human primate? cattle?) present for a long time in Africa. This hypothesis fits well with retrospective serological data strongly suggesting that the AIDS virus or a related virus has been present in Africa since the early sixties and that its prevalence at that time was very low $(0.2 \%)(16)$. To date, although limited, the various surveys point to the Central African belt as an important focus of HTLV-III/LAV infections among heterosexual populations (19). The virus is not yet endemic to the Southern and Northern part of Africa (17). It is new to Kenya, as shown by the rising prevalence of HTLV-III/ LAV antibodies in prostitutes of Nairobi which has increased from $4 \%$ in 1981 to $59 \%$ in 1985 (18). It is likely that it has been present in Uganda, Rwanda, and Zaïre for a longer time. Although present in Equatorial Africa since a few decades ago, HTLV-III/LAV infection took an epidemic evolution only a few years ago. The main heterosexual mode of transmission of the AIDS virus in Africa and the socio-economic background of African tropical countries during the past three decades could explain why the epidemic has appeared only recently.

Heterosexual transmission of AIDS virus is likely to be less efficient than homosexual transmission (20) as exemplified by the ten-fold increase (from 0.25 to $3 \%$ ) in seropositivity during the years 1970-1980 among the group of mothers in Kinshasa (21). During the same period, a 500 -fold increase would be expected among Western homosexual males. However, as the infection spreads in Africa, and as the disease becomes common, the chances of getting the virus are increasing and the development of the number of cases remains explosive. Indeed, for 1984 the estimated annual incidence of AIDS in Kinshasa is 55-100 cases per 100,000 (P. Piot: personal communication) which is similar to the incidence of $82-100 / 100,000$ calculated for recent Haitian immigrants to the United States (22) and which is 50 - to 100 - fold higher than the incidence of AIDS in most European countries. Uncontrolled growth of urban centers, extension of female prostitution, disruption of family units, urban immigration of male workforce, movement of various armies and breakdown of the health services, are all events which have occurred more or less predominantly during the last three decades in most African Equatorial countries, promoting the transmission of AIDS virus and its transcontinental spread.

There are sharp discrepancies between the epidemiology

N. Clumeck, M.D., Division of Infectious Diseases, St. Pierre University Hospital, Rue Haute, 322, B-1000 Brussels. 
of AIDS in developing countries and in the United States and Europe. African AIDS is a disease of young middle aged sexually active men and women (2). It also affects children less than 5 years old. Although in the U.S.A. female to male sexual transmission of HTLV-III/LAV has been less evident than male to female sexual transmission, epidemiological evidence pleads for an efficient bidirectional transmission of the virus in Africa. A case controlled study in heterosexual African men with AIDS in Belgium and Rwanda showed a significant association of HTLV-III/LAV infection with a history of contact with prostitutes and with an increased number of female partners per year (23). Furthermore, the finding of very high seropositivity among female prostitutes in Rwanda (24) and in Nairobi (25) supports the evidence, as for other STD's, that female prostitutes are a high risk group and also a likely reservoir of the pathogen. In Europe and the United States, seropositive i.v. drug users who are also female prostitutes could help to spread AIDS virus infection in the general heterosexual population. However, this has as yet not been observed, since in the U.S.A. only $1 \%$ of AIDS cases are thought to have acquired the disease by heterosexual contact. These differences between Northern countries and Africa could be due to differences in co-factors such as the coexistence of other sexually transmitted diseases (genital ulceration) or behavioural factors (vaginal contacts during menses, trauma during sex, anal sex) which, however, have not yet been clearly investigated in Africa.

\section{Literature}

1. Clumeck, N., Mascart-Lemone, F., de Maubeuge, J., Brenez, D., Marcelis, L.: Acquired immune deficiency syndrome in black Africans. Lancet I (1983) 642.

2. Clumeck, N., Sonnet, J., Taelman, H., Mascart-Lemone, F., De Bruyère, M., Van de Perre, P., Dasnoy, J., Marcelis, L., Lamy, M., Jonas, C., Eyckmans, L., Noel, H., Vanhaeverbeek, M., Butzler, J. P.: Acquired immunodeficiency syndrome in African patients. N. Eng. J. Med. 310 (1984) 492-497.

3. Clumeck, N., Sonnet, J., Taelman, H., Cran, S., Henrivaux, P.: Acquired immune deficiency syndrome in Belgium and its relation to Central Africa. Annals of the New York Academy of Sciences 437 (1984) 264-269.

4. Update: Acquired immunodeficiency syndrome-Europe. Morbidity and Mortality Weekly Report 35 (1986) 3.

5. Van de Perre, P., Rouvroy, D., Lepage, P., Bogaerts, J., Kestelyn, P., Kayhigi, J., Hekker, A. C., Butzler, J. P., Clumeck, N.: Acquired immunodeficiency syndrome in Rwanda. Lancet II (1984) $62-69$.

6. Piot, P., Quinn, T. C., Taelman, H., Feinsod, F. M., Minlangu, K. B., Wobin, O., Mbendi, N., Mazebo, P., Ndangi, K., Stevens, W., Kalambayi, K., Mitchell, S., Bridts, C., McCormick, J. B.: Acquired immunodeficiency syndrome in a heterosexual population in Zaire. Lancet II (1984) 65-70.

7. Bayley, A. C.: Aggressive Kaposi's sarcoma in Zambia, 1983. Lancet I (1984) 1318-1320.

8. Serwadda, D., Mugerwa, R. D., Sewankambo, N. K., Lwegaba, A., Carswell, J. W., Kirya, G. B., Bayley, A. C., Downing, R. G., Tedder, R. S., Clayden, S. A., Weiss, R. A., Dalgleish, A. G.: Slim disease, a new disease in Uganda and its association with HTLV-III infection. Lancet II (1985) 849-852.
Blood transfusion as another mode of transmission of AIDS virus in Africa, is also likely to occur but has not yet been assessed. However, in limited surveys of middle aged urban males in Rwanda, a high prevalence of HTLV-III/LAV-positive sera of $15 \%$ has been found (19). In Central Africa patients with sickle cell anemia could be the counterpart of hemophilic patients in Europe and the U.S.A. (30). The lack of public health measures in Equatorial Africa, such as obligatory screening of blood donors, will certainly contribute to the AIDS epidemic in the future in that continent.

The heterosexual versus needle transmission of AIDS virus in Africa has raised passionate debates (26-29). However, to date, all the epidemiological evidence strongly argues against a predominant needle (or insect-borne) transmission. It must be noted that the "needle hypothesis" is reassuring for the developed countries where the problem of the multiple use of non-sterilized needles remains confined to the i.v. drug user group.

In contrast to Europe or the U.S.A., in Central Africa AIDS is mainly a heterosexually transmitted disease. In this view, the African epidemic could therefore be a possible vision of America's and Europe's future. There is then an urgent need to clarify those factors which favour heterosexual transmission and to take adequate measures aimed at avoiding the further extension of HTLV-III/ LAV infection from limited groups of bisexual or heterosexual i.v. drug users to the general population in Western countries.

9. Norman, C.: Politics and science clash on African AIDS. Science 230 (1985) 1140-1142.

10. Silver, G.: Collective madness. Lancet I (1986) 609.

11. Benn, S., Rudledge, R., Folks, T., Baker, L., McCormick, J., Feorino, P., Piot, P., Quinn, T., Martin, M.: Genomic Heterogenicity of AIDS retroviral isolates from North America and Zaïre. Science 230 (1985) 949-951.

12. Clavel, F., Brun-Vézinet, F., Guétard, D., Chamaret, S., Laurent, A., Rouziaux, C., Rey, M., Katlama, C., Rey, F., Champelinaud, J. L., Nina, J. S., Mansinho, K., Santos-Ferreira, M. O., Klatzman, D., Montagnier, L.: LAV type II: un second rétrovirus associé au SIDA en Afrique de l'Ouest. C. R. Acd. Sc. Paris (1986) 302-III, 13: 485-488.

13. Barin, F., M'Boup, S., Denis, F., Kanki, P., Allan, J. S., Lee, T. H., Essex, M.: Serological evidence for virus related to simian T-lymphotropic retrovirus III in residents of West Africa. Lancet II (1985) 1387-1389.

14. Kanki, P. J., Barin, F., M'Boup, S., Allan, J. S., Romet-Lemonne, J. L., Marlink, R., McLane, M. F., Lee, T. H., Arbeille, B., Denis, F., Essex, M.: Science 232 (1986) 238-243.

15. Thiry, L., Sprecher-Goldberger, S., Jacquemin, P., Cogniaux, J., Burny, A., Bruck, C., Portetelle, D., Cran, S., Clumeck, N.: Bovine leukemia virus-related in lymphocyte cultures infected with AIDS-associated viruses. Science 227 (1985) 1482-1484.

16. Nahmias, A., Weiss, J., Yao, X., Lee, F., Kodsi, R., Motulsky, A., Schanfield, M.: Antibody to HTLV-III/LAV in serum from Central Africa in 1959. International Symposium on African AIDS, Brussels, Belgium, November 22-23, 1985, Abstract P03.

17. Lyons, S. F., Schoub, B. D., McGillivray, G. M., Sher, R., Dos Santos, L.: Lack of evidence of HTLV-III endemicity in Southern Africa. N. Eng. J. Med. 312 (1985) 19: 1257-1258. 
18. Piot, P., Plummer, F. A., Rey, M., Ngugi, E. N., Rouziaux, C., Ndinya-Achola, J. O., D'Costa, L. J., Vercauteren, G.: Retrospective seroepidemiology of AIDS virus infection in Nairobi populations. International Conference on Acquired Immunodeficiency Syndrome (AIDS), Paris, France, June 23-25, 1986.

19. Clumeck, N., Robert-Guroff, M., Van de Perre, P., Jennings, A., Sibomana, J., Demol, P., Cran, S., Gallo, R. C.: Seroepidemiological studies of HTLV-III antibody prevalence among selected groups of heterosexual Africans. JAMA 254 (1985) 18: 2599-2602.

20. Wofsy, C. B., Cohen, J. B., Hauer, L. B., Padian, N. S., Michaelis, B. A., Evans, L. A., Levy, J. A.: Isolation of AIDS-associated retrovirus from genital secretions of women with antibodies to the virus. Lancet I (1986) 527-529.

21. Desmyter, J., Goubau, P., Chamaret, S., Montagnier, L.: AntiLAV/HTLV-III in Kinshasa mothers in 1970 and 1980. International Conference on Acquired Immunodeficiency Syndrome (AIDS), Paris, France, June 22-25, 1986.

22. Hardy, A. M., Allen, J. R., Morgan, W. M., Curran, J. W.: The incidence rate of acquired immunodeficiency syndrome in selected populations. JAMA 253 (1985) 2: 215-220.

23. Clumeck, N., Van de Perre, P., Carael, M., Rouvroy, D., Nzaramba, D.: Heterosexual promiscuity among African patients with AIDS. N. Eng. J. Med., July 18 (1985) 182.
24. Van de Perre, P., Clumeck, N., Carael, M., Nzabihimana, E., Robert-Guroff, M., De Mol, P., Freyens, P., Butzler, J. P., Gallo, R. C., Kanyamupira, J. B.: Female prostitutes: a risk group for infection with human T-cell lymphotropic virus type III. Lancet II (1985) 524-526.

25. Kreiss, J. K., Koech, D., Plummer, F. A., Holmes, K. K., Lightfoote, M., Piot, P., Ronald, A. R., Ndinya-Achola, J. O., D'Costa, L. J., Roberts, P., Ngugi, E. N., Quinn, T. C.: AIDS virus infection in Nairobi prostitutes. Spread of the epidemic to East Africa. N. Eng. J. Med. 314 (1986) 7: 414-418.

26. Dalgleish, A. G.: Sexual transmission of AIDS. Br. J. Hosp. Med. 314 (1985).

27. Schultz, S., Milberg, J. A., Kristal, A. R., Stoneburner, R. L.: Female to male transmission of HTLV-III. JAMA 255 (1986) 13: 1703-1704.

28. Wykoff, R. F.: Female to male transmission of HTLV-III. JAMA 255 (1986) 13:1704-1705.

29. Redfield, R. R., Wright, D. C., Markham, P. D., Salahuddin, S. Z., Sarngadharan, M. G., Gallo, R. C.: Female to male transmission of HTLV-III. JAMA 255 (1986) 13: 1705-1706.

30. Izzia, K. W., Lepira, B., Kayembe, K., Odio, W.: Syndrome d'immunodéficience acquise et drépanocytose homozygote. A propos d'une observation Zaïroise. Ann. Soc. Belge Med. Trop. 64 (1984) 391-396. 